\title{
Cell signalling compound improves pasture and livestock productivity and the environment
}

\author{
Usha Amaranathan • Nathan Balasingham
}

Received: 17 August 2020/Accepted: 12 January 2022/Published online: 11 February 2022

(C) The Author(s) 2022

\begin{abstract}
A biogenic agricultural compound enables pasture to synthesise more soluble sugars and delivers benefits attributable to bioactive molecules: phenylpropanoids. Phenylpropanoids are plant secondary compounds that help plants overcome biotic and abiotic stress to increase pasture quality and yield. When consumed by ruminants, phenylpropanoids improve the conversion efficiency of pasture protein to milk and meat. The effect of this compound, trademarked Biozest ${ }^{\mathrm{TM}}$, on pasture and ruminant efficiency was evaluated via split block trials followed by full scale, full life cycle, on-farm trials. Aspects measured include pasture resilience, quality and productivity, livestock productivity and urea excretion. Biozest ${ }^{\mathrm{TM}}$ improved pasture resilience, quality, and yield by over $75 \%$. Soluble sugar content of the pasture increased (18\%). When livestock grazed Biozest $^{\mathrm{TM}}$ treated pasture, urea excretion was reduced (20-48\%), and milk and meat production increased $(30 \%)$. The pasture, livestock productivity and urea benefits of Biozest ${ }^{\mathrm{TM}}$ have been established. Trial results support the following inferences. First, the fermentation of the increased soluble carbohydrates in Biozest treated pasture would result in increased propionates and less acetoclastic methanogenesis. Second, the reduction in urea excretion and increase in livestock productivity would result from a reduction
\end{abstract}

U. Amaranathan $(\bowtie) \cdot N$. Balasingham

Zest Biotech, Auckland, New Zealand

e-mail: usha@zestbiotech.co.nz in the proportion of dietary protein digested to ammonia and reduced deamination of some of the ammonia to urea. Further, due to the reduced deamination, fewer carbonyls and hydride moieties would be available for methylotrophic and hydrogenotrophic methanogenesis. Future work may include quantification or modelling of increased carbon dioxide sequestration and quantification of the reduction in nitrous oxide and methane emissions.

Keywords Phenylpropanoids · Methane emission · Greenhouse gas · Agriculture - Ruminant efficiency · Pasture

\section{Introduction}

Energy lost as methane $\left(\mathrm{CH}_{4}\right)$ and feed protein wasted as urea are two significant inefficiencies inherent in ruminant production systems (Eckard et al. 2010). Addressing these inefficiencies can reduce environmental liabilities and increase productivity (Leng 1991).

On average, ruminants convert $24.7 \%$ of feed nitrogen $(\mathrm{N})$ into milk or meat (Hristov and Jouany 2005). Seventy five per cent $(75 \%)$ of feed $N$ is wasted as urine or dung urea (Hristov and Jouany 2005). In addition, cattle typically lose $6 \%$ of their ingested energy as eructated $\mathrm{CH}_{4}$ (Johnson and Johnson 1995). Therefore, ruminant metabolic inefficiency 
significantly impacts farm productivity and the emission of $\mathrm{CH}_{4}$ and nitrous oxide $\left(\mathrm{N}_{2} \mathrm{O}\right)$, both of which are greenhouse gases (GHGs).

GHGs are gases in the atmosphere such as water vapour, carbon dioxide, $\mathrm{CH}_{4}$ and $\mathrm{N}_{2} \mathrm{O}$ that can absorb infrared radiation, trapping heat in the atmosphere. This process, known as the greenhouse effect, means that emissions of GHGs due to human activity contribute to global warming (IPCC 2019). $\mathrm{N}_{2} \mathrm{O}$ and $\mathrm{CH}_{4}$ have 265 and 28 times, respectively (with the inclusion of climate-carbon feedbacks) the global warming potential of carbon dioxide over 100 years (IPCC 2014). Therefore, a small reduction in urea excretion and $\mathrm{CH}_{4}$ eructation can significantly decrease farm GHG liabilities.

A small increase in the percentage of feed protein converted to milk or meat can deliver a substantial increase in farm productivity. For example, a feed protein conversion increase of $2.5 \%$ (from $25 \%$ to $27.5 \%$ ) can deliver a $10 \%$ increase in farm productivity. In addition, increasing the conversion efficiency of pasture protein into milk or meat results in less waste as urea and $\mathrm{CH}_{4}$, thus increasing productivity while reducing environmental impacts and GHG emissions.

There are two probable processes for reducing methanogenesis during ruminant fermentation. One strategy is to increase the relative amount of soluble carbohydrates in pasture (Theodorou et al. 2006). The fermentation of these soluble carbohydrates is less methanogenic than the fermentation of cell wall carbohydrates (Moe et al. 1979; Wang et al. 2018). The second strategy for improving feed conversion efficiency in ruminants is to reduce urea excretion by reducing the amount of pasture protein converted into ammonia $\left(\mathrm{NH}_{3}\right)$ in the rumen (Theodorou et al. 2006).

Phenylpropanoids are compounds with a chain of 3 carbons bound to an aromatic ring of 6 carbons (Calsamiglia et al. 2007). Plants produce a range of phenylpropanoids, including anthocyanins, flavonoids, isoflavonoids, flavones, lignin, suberin and coumestrol (Dixon and Paiva 1995). Phenylpropanoids have several roles in plant health and growth. Isoflavonoids, for example, strengthen the defence system against pest and disease damage (Chinnusamy et al. 2003), thus improving plant health. Scientific evidence also substantiates farmers' assertions that phenylpropanoids improve animal health (Theodorou et al. 2006).
Phenylpropanoids can improve pasture productivity by reducing pest, disease and environmental (drought, waterlogging, wind, cold, salinity and light) stress (Dixon and Paiva 1995). Phenylpropanoids also signal soil microbes involved in nutrient procurement (Harrison and Baldwin 2004). For example, phenylpropanoids secreted by plant roots act as signals to attract $\mathrm{N}$ fixing bacteria (Hassan and Mathesius 2012). Phenylpropanoids also promote the development of mycorrhizal fungi that are crucial for phosphate uptake and enhance nutrient availability through chelation and mineralisation of soil calcium, iron and phosphates (Harrison and Baldwin 2004).

Phenylpropanoids in plants and pasture have beneficial effects on rumen fermentation, microbial populations, meat and milk production, feed conversion efficiency and $\mathrm{CH}_{4}$ inhibition (Patra 2011). In addition, an increased phenylpropanoid content in pasture increases the content of conjugated linoleic acids, the health promoting fatty acids found in milk and meat produced by pasture fed ruminants (Patra 2011). A higher content of phenylpropanoids in pasture can shift the type of $\mathrm{N}$ excreted in urine and dung from a soluble form to an insoluble form of $\mathrm{N}$ (Patra 2011), which has a beneficial effect on $\mathrm{N}$ cycling and the reduction of leaching.

Plants have membrane anchored molecular pattern recognition receptors (Panstruga et al. 2009). These receptors monitor extracellular biotic stress messenger molecules and abiotic stress sensory messages. One of the mechanisms of response to both abiotic and biotic stress signalling molecules is the induction and upregulation of the phenylpropanoid metabolic pathway in plants (Dixon and Paiva 1995; Sharma et al. 2019).

Knowledge of the presence of such receptors and the mechanisms by which microorganisms, plants and animals respond to each other (Harrison and Baldwin 2004), the environment (Chinnusamy et al. 2003), and defend against pathogens and pests (Nürnberger et al. 2004) enabled the development of a novel agricultural compound, Biozest ${ }^{\mathrm{TM}}$.

Biozest $^{\mathrm{TM}}$ is a molecular pattern recognition receptor (MPR) signalling agricultural compound. The application of Biozest ${ }^{\mathrm{TM}}$ on crops and pasture delivers the range of phenomena attributable to phenylpropanoid cascades (Indigo Limited, unpublished reports). The full mechanism of the observed biological response has yet to be determined. 
However, field observations and data from several crops support the hypothesis that the membrane bound receptors on plants recognise and react to Biozest ${ }^{\mathrm{TM}}$ applications: inducing and sustaining the innate production of phenylpropanoid cascades.

This study examined the effect of Biozest ${ }^{\mathrm{TM}}$ on pasture productivity, milk and meat production and consequent impacts on urea excretion in pastoral farming systems. We hypothesised that the application of this compound on pasture would increase the availability of soluble carbohydrates and induce and sustain the production of phenylpropanoids. This pasture response might improve the feed conversion efficiency of ruminants that consume the treated pasture, leading to increased milk/meat production and reduced urea excretion and emissions of $\mathrm{N}_{2} \mathrm{O}$ and $\mathrm{CH}_{4}$.

\section{Method}

Biozest $^{\mathrm{TM}}$ is a gene mediated technology and engages ecologically through multitrophic interactions. This complexity, combined with the number of benefits delivered, makes conventional replicated small plot evaluations highly variable and underpowered. A systems biology approach was employed to account for complex, multilevel interactions. The experimental design selected enabled the assessment of plant and ruminant responses in their natural or typical setting (Fang and Casadevall 2011). Trials were thus carried out in 'real world conditions' (Merfield and Johnson 2013) on commercial farms to establish the effect of Biozest $^{\mathrm{TM}}$ pasture treatments and the consequent commercial benefits such as increased pasture productivity, milk production and quality and animal liveweight.

When assessing emissions mitigation strategies, the whole-farm impact must be examined (Eckard et al. 2010). This supported the decision to use large-scale trials for the assessment of Biozest ${ }^{\mathrm{TM}}$. Whole-farm system modelling and life-cycle assessments were employed to ensure production, quality and overall farm productivity were accounted for.

Pasture productivity and palatability

Pasture dry matter (DM) was measured using a statistically verified, industry standard method
(Litherland et al. 2008). Rising plate pasture meters were used to measure the standard compression height of the sward, which was then converted to $\mathrm{DM} \mathrm{ha}^{-1}$ via the standardised industry measurement and DM calculation protocol.

\section{Pasture growth and DM production}

Two (2) paddocks (paddocks 40 and 42) were selected and split into two on a New Zealand dairy farm in Taranaki. Two (2) sprays of Biozest ${ }^{\mathrm{TM}}$ were applied at a rate of $1 \mathrm{~L} \mathrm{ha}^{-1}$ to one half of each paddock. The first spray was applied on 11 June 2009. The second spray was applied 7 days later. Pasture growth (measured as DM production) was measured across both paddocks on 30 June 2009 (19 days after the first Biozest ${ }^{\mathrm{TM}}$ treatment).

\section{Pasture growth and DM consumption (palatability)}

A trial to assess productivity and palatability was conducted on a dairy farm in Northland, New Zealand. Half of the paddock was treated with Biozest ${ }^{\mathrm{TM}}$ at the recommended rate of $1 \mathrm{~L} \mathrm{ha}^{-1}$. The sprays were applied on 03 September and 07 September 2009. In this paddock, the DM measurements were taken before grazing (on 15 October 2009) and after grazing (on 19 October 2009).

\section{Pasture productivity: cut baleage}

A baleage harvest trial was conducted on two dairy farms located on the Hauraki Plains, Waikato, New Zealand. The two farms, owned and managed by one family, were located side by side and received similar management. Two (2) sets of paddocks on each farm were set aside for baleage production (Set A and Set B). One (1) farm was treated with Biozest ${ }^{\mathrm{TM}}$ twice (on 26 and 30 June 2017) as per the label directions, while the control farm received no Biozest ${ }^{\mathrm{TM}}$ treatments. Due to wet conditions, Set A paddocks were not grazed post treatment. Set A was cut on 21 November 2017. Set B paddocks were grazed, and a $3^{\text {rd }}$ Biozest $^{\mathrm{TM}}$ treatment was applied 3 days after grazing on 13 September 2017. Set B was cut on 24 November 2017. The number of bales per paddock was recorded and converted to bale production ha ${ }^{-1}$. The yield from the Biozest ${ }^{\mathrm{TM}}$ treated farm was compared to the untreated control farm. 
Environmental stress tolerance

Stress tolerance trials were carried out on a dairy farm in Northland, New Zealand. Three paddocks were selected to provide a range of environmental conditions, pasture compositions and management variations within the farm. The paddocks were split into two, and the recommended Biozest ${ }^{\mathrm{TM}}$ treatment programme was applied to the treated half: $1 \mathrm{~L}$ Biozest $^{\mathrm{TM}}$ in $500 \mathrm{~L}$ water ha ${ }^{-1}$. Two (2) applications 5 days apart were applied, followed by a $3^{\text {rd }}$ application 3 to 5 days after grazing. DM production was measured using a rising plate meter before and after grazing. The trials were carried out in 2010 .

\section{Drought and frost tolerance}

A paddock was selected with assistance from the farmer for the assessment of drought and frost tolerance. In 2010 this region experienced drought (January-April) and frosts in June-August, unusual for this northern region (NIWA 2011). The drought was described by the National Institute of Water and Atmospheric Research as the worst in the Northland region in 60 years when just $253 \mathrm{~mm}$ of rain fell between November 2009 and April 2010 (Tait 2011).

\section{On drought tolerant pasture}

A mixed pasture paddock: $60 \%$ ryegrass and $40 \%$ Kikuyu (Pennisetum clandestinum) was selected. Kikuyu has been shown to perform well compared to other common forage species (including ryegrass) in drought or low rainfall conditions (Neal et al. 2009).

\section{Soil and water stress}

On the same Northland farm, Biozest ${ }^{\mathrm{TM}}$ treatments were applied to a swampy/waterlogged paddock. The farmer identified that soil/water stress conditions typically occurred in this paddock in winter/spring when the soil becomes waterlogged and again in summer when the shallow rooted pasture is stressed and dries off early in the season.
Stock condition and weight gain (Angus stud bulls)

In 2011 on a farm in Oparau, Waikato, New Zealand, a herd of 40 Angus stud bulls was divided into two. Twenty (20) bulls grazed on 20 ha of untreated pasture while 20 bulls grazed on 20 ha of Biozest ${ }^{\mathrm{TM}}$ treated pasture throughout the 10-week finishing period. Two (2) Biozest ${ }^{\mathrm{TM}}$ treatments were applied by helicopter one week apart at a rate of $1 \mathrm{~L} \mathrm{ha}^{-1}$. The bulls then grazed the pasture for 68 days. The bulls were weighed at the start and the end of the finishing period. The bulls were then sent to a sales auction, where the price achieved for each bull was recorded.

Soluble carbohydrate assessment

A split block/paddock experimental design was applied on a dairy goat farm in Pukeatua, Waikato, New Zealand. Biozest ${ }^{\mathrm{TM}}$ was applied to half the paddock at a rate of $1 \mathrm{~L} \mathrm{ha}^{-1}$. Two (2) initial applications were made close together (5 days apart). Follow on treatments were applied 3 to 5 days after grazing throughout the season. The pasture was tested for soluble solids using a hand-held digital refractometer every 7 days for 28 days following the method recommended by Novel Technologies (Balsom and Lynch 2008). Sampling was undertaken on a clear day when the pasture was dry. The pasture samples were rolled by hand for 60 seconds, and juice exuding from the sample was squeezed directly onto a refractometer. Values were expressed in ${ }^{\circ}$ Brix.

The same assessment methodology was applied on a sheep farm in Auckland, New Zealand. A paddock was split in half and received 3 applications of Biozest $^{\mathrm{TM}}$ at a rate of $1 \mathrm{~L} \mathrm{ha}^{-1}$. Seven (7) days after the $3^{\text {rd }}$ application, samples were alternately taken from the treated and control side of the paddock. Six (6) samples were taken from each side.

Milk production and quality

Dairy goats on a farm in Pukeatua, Waikato, New Zealand, were fed pasture from paddocks treated with Biozest $^{\mathrm{TM}}$ and control paddocks in cycles. Biozest ${ }^{\mathrm{TM}}$ treatments were applied at the rate of $1 \mathrm{~L} \mathrm{Biozest}^{\mathrm{TM}}$ in $500 \mathrm{~L}$ water $\mathrm{ha}^{-1}$. Two (2) initial applications were made close together (5 days apart). Follow on treatments were applied 3 to 5 days after grazing throughout the season. The results reported were 
extracted from the supply and quality report data from Dairy Goat Co-operative Ltd.

A milk production trial was carried out on a dairy farm on the Hauraki Plains, Waikato, New Zealand. Biozest $^{\mathrm{TM}}$ treatments were applied, beginning in late summer 2012, at the rate of $1 \mathrm{~L} \mathrm{Biozest}^{\mathrm{TM}}$ in $500 \mathrm{~L}$ water $\mathrm{ha}^{-1}$. Two (2) initial applications were made close together (5 days apart). Follow on treatments were applied 3 to 5 days after grazing throughout the season. Gestating cows grazed Biozest ${ }^{\mathrm{TM}}$ treated pasture and untreated pasture in cycles of approximately 8 to 10 days from 02 February to 20 April. The milk production results were extracted from the cooperative milk processor's supply and quality analysis report.

\section{Urea discharge}

Urine samples were taken from the herd described previously in the dairy goat trial in Pukeatua. Five (5) goats were selected at random, and urine samples were collected. Samples were collected during each feeding cycle on Biozest ${ }^{\mathrm{TM}}$ treated or untreated control pasture. Each round of sample collection was carried out 2 to 3 days before the stock were shifted onto Biozest $^{\mathrm{TM}}$ treated or control pasture feed. The urine urea and creatinine levels in the urine were determined by an independent laboratory, Gribbles Veterinary, using an automated analyser (Hitachi Modular, Roche Diagnostics Corporation, Indianapolis, IN, United States of America) with kits supplied by Roche Diagnostics Corporation.

Urine samples from 5 randomly selected cows were collected from a dairy farm on the Hauraki Plains, Waikato, New Zealand. Samples were collected during each cycle of grazing on either Biozest ${ }^{\mathrm{TM}}$ treated or untreated control pasture. Each round of sample collection was carried out 2 to 3 days before the stock were shifted onto Biozest ${ }^{\mathrm{TM}}$ treated or control pasture.

Case study: sheep and cattle farm

Alpha testing of the technology was carried out on 2 sheep and cattle farms that have been farmed by the same family for several generations. The two farms are Mangapapa (309 ha), the control farm, and Haumai (201.7 ha), the Biozest ${ }^{\mathrm{TM}}$ treated farm. In previous years, the productivity of both farms was in the upper quartile for the Waikato region. The Biozest ${ }^{\mathrm{TM}}$ treatment was applied by helicopter at a rate of $1 \mathrm{~L}$ Biozest $^{\mathrm{TM}}$ in $50 \mathrm{~L}$ water $\mathrm{ha}^{-1}$. Two (2) initial applications were made close together ( 3 to 5 days apart) in winter 2016 , followed by 1 X $1 \mathrm{~L} \mathrm{ha}^{-1}$ applied in spring, summer, autumn and winter. Pasture production and stock liveweight were monitored. The FARMAX (Farmax Ltd 2013) farm modelling tool was used to model the complexity and variables in the farm system and predict the biological and financial outcomes.

Statistical analysis

T-tests for statistical significance are reported for each trial. Two-tailed unpaired homoscedastic t-tests were used for the urea trial results. Two-tailed paired homoscedastic t-tests were used for the other trials. Measurement variables are approximately normally distributed, and other assumptions are consistent with the t-test.

\section{Results}

Pasture productivity

Pasture growth and DM production

Nineteen (19) days after the first Biozest ${ }^{\mathrm{TM}}$ treatment, pasture DM production in the treated halves of paddock 40 and paddock 42 had increased by $89 \%$ and $127 \%$, respectively, compared to the control half of each paddock $(p=0.03)$ (Table 1$)$.

\section{Pasture growth and DM production (palatability)}

The results (Table 2) confirm that pasture DM production on this Northland dairy farm was $23 \%$ greater in the Biozest ${ }^{\mathrm{TM}}$ treated area, and the cows consumed $21 \%$ more DM from the treated part of the paddock compared to the control. The cows preferentially grazed the treated pasture, consumed more DM and grazed the pasture evenly and closer to the ground in the treated area compared to the control area. 
Table 1 Effect of pasture treatment on DM production

\begin{tabular}{|c|c|c|c|c|c|c|c|}
\hline \multirow{2}{*}{$\begin{array}{l}\text { Paddock } \\
\text { No }\end{array}$} & \multicolumn{3}{|l|}{ Treated } & \multicolumn{3}{|l|}{ Control } & \multirow{2}{*}{$\begin{array}{l}\text { Productivity increase in treated } \\
\text { area }(\%)\end{array}$} \\
\hline & $\begin{array}{l}18 \text { June } \\
(\mathrm{kg} \mathrm{DM} \\
\left.\mathrm{ha}^{-1}\right)\end{array}$ & $\begin{array}{l}30 \text { June } \\
(\mathrm{kg} \mathrm{DM} \\
\left.\mathrm{ha}^{-1}\right)\end{array}$ & $\begin{array}{l}\text { Productivity } \\
(\mathrm{kg} \mathrm{DM} \\
\left.\mathrm{ha}^{-1}\right)\end{array}$ & $\begin{array}{l}18 \text { June } \\
(\mathrm{kg} \mathrm{DM} \\
\left.\mathrm{ha}^{-1}\right)\end{array}$ & $\begin{array}{l}30 \text { June } \\
(\mathrm{kg} \mathrm{DM} \\
\left.\mathrm{ha}^{-1}\right)\end{array}$ & $\begin{array}{l}\text { Productivity } \\
(\mathrm{kg} \mathrm{DM} \\
\left.\mathrm{ha}^{-1}\right)\end{array}$ & \\
\hline 40 & 1790 & 2311 & 521 & 1940 & 2215 & 275 & 89 \\
\hline 42 & 2021 & 2651 & 630 & 1987 & 2264 & 227 & 127 \\
\hline
\end{tabular}

Table 2 Rising Plate meter measurement of DM production before grazing and after grazing

\begin{tabular}{llll}
\hline & Sample Date & $\begin{array}{l}\text { Treated } \\
\left(\mathrm{kg} \mathrm{DM} \mathrm{ha}^{-1}\right)\end{array}$ & $\begin{array}{l}\text { Control } \\
\left(\mathrm{kg} \mathrm{DM} \mathrm{ha}^{-1}\right)\end{array}$ \\
\hline After grazing & $4 / 08 / 2010$ & 995 & 1164 \\
Before grazing & $15 / 10 / 2010$ & 1797 & 1816 \\
After grazing & $19 / 10 / 2010$ & 540 & 776 \\
Increase in growth (between grazing) $_{\text {DM consumed }^{a}}$ & 802 & 652 \\
\hline
\end{tabular}

${ }^{\mathrm{a}} \mathrm{DM}$ consumed is significantly different between treatments $(p=.004)$

Pasture productivity: cut baleage

In set $\mathrm{A}$, Baleage production $\mathrm{ha}^{-1}$ in the Biozest ${ }^{\mathrm{TM}}$ treated paddocks was $117 \%$ greater than the production in the control set of paddocks $(p=0.005)$ (Table 3). In Set B, baleage production $\mathrm{ha}^{-1}$ in the Biozest $^{\mathrm{TM}}$ treated paddocks was $115 \%$ greater than the production in the control paddocks $(p=0.02)$ (Table 3).

Environmental stress tolerance

During the drought period, DM consumed $\mathrm{ha}^{-1}$ was much higher (121\% higher in January, 260\% higher in April) on the Biozest ${ }^{\mathrm{TM}}$ treated portions of the split paddocks compared to the control $(p=0.001)$ (Fig. 1a). During the frost period, DM consumed ha $^{-1}$ was $85 \%$ higher in June, and $107 \%$ higher in August on the Biozest ${ }^{\mathrm{TM}}$ treated portions of the split paddocks compared to the control portions (Fig. 1a).

In the mixed pasture (60\% ryegrass and $40 \%$ drought tolerant Kikuyu (Pennisetum clandestinum)), the stock consumed $85 \%$ more DM in the Biozest ${ }^{\mathrm{TM}}$ treated area than the control area across all seasons $(p=0.004)$ (Fig. 1b).

In a paddock prone to drying in late summer and waterlogging in winter, DM consumption in the
Biozest $^{\mathrm{TM}}$ treated area was $489 \%$ greater in February and $51 \%$ greater in August compared to the untreated area $(p=0.001)$ (Fig. 1c).

Stock condition and weight gain (Angus stud bulls)

The 20 bulls that grazed on 20 ha of treated pasture gained an extra 22\% ( $p=0.008)$ in liveweight during the 68-day finishing period compared to the control bulls. Bulls that grazed Biozest ${ }^{\mathrm{TM}}$ treated pasture realised higher bids than those that grazed the untreated area at auction. The net return $\mathrm{ha}^{-1}$ increased by NZ\$1,645 (Table 4).

Soluble carbohydrate assessment

Samples taken every 7 days over a 28-day testing period on the Pukeatua dairy goat farm showed Brix levels ranged from 2 to $5^{\circ}$ in both the treated and untreated pasture. Brix levels in the treated pasture were generally $1^{\circ}$ higher in the Biozest ${ }^{\mathrm{TM}}$ treated area compared to the control. On an Auckland sheep farm, where multiple samples were taken alternately from treated and untreated paddocks, Brix levels were 1.97 ${ }^{\circ}$ Brix, or $18 \%$ higher, in the treated area than in the control area $(p=0.005)$. 
Fig. 1 Effect of pasture treatment on dry matter consumed on a Northland dairy farm under various stress conditions and pasture types: a on pasture under drought and frost conditions, b on drought tolerant pasture species and $\mathbf{c}$ on pasture under soil/water stress (a)

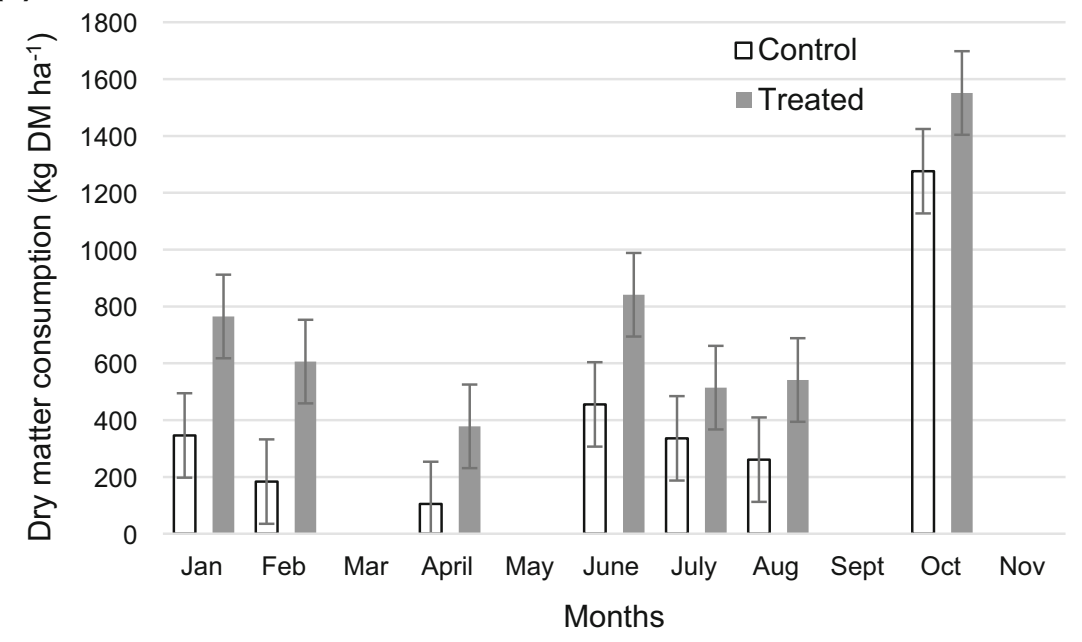

(b)

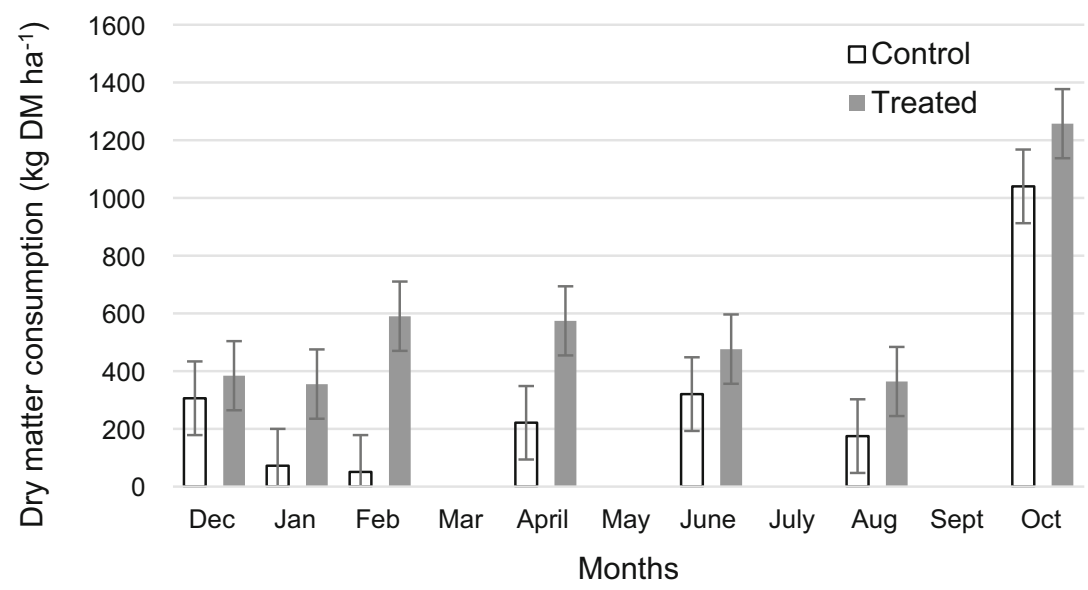

(c) 1600

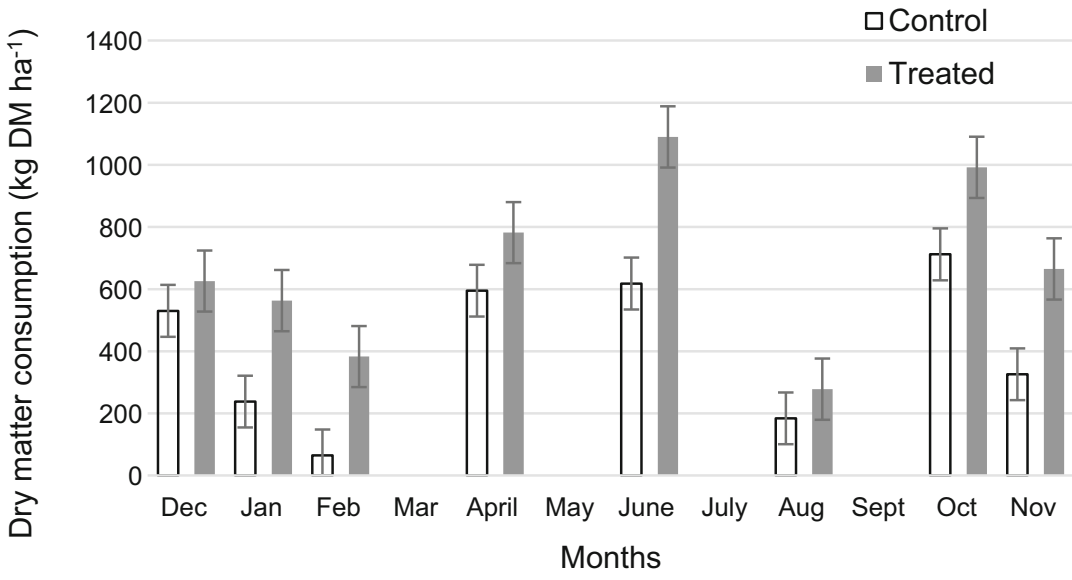


Table 3 Baleage production

\begin{tabular}{|c|c|c|c|c|c|c|c|c|}
\hline & \multicolumn{4}{|l|}{ Treated } & \multicolumn{4}{|l|}{ Control } \\
\hline & Paddock No & ha & Bales & 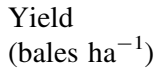 & Paddock No & ha & Bales & $\begin{array}{l}\text { Yield } \\
\text { (bales ha }^{-1} \text { ) }\end{array}$ \\
\hline \multicolumn{9}{|l|}{ Set A } \\
\hline & 16 & 2.51 & 36 & 14.3 & 4 & 2.16 & 12 & 5.6 \\
\hline & 15 & 2.26 & 23 & 10.2 & 5 & 2.1 & 14 & 6.7 \\
\hline & 14 & 2.19 & 19 & 8.7 & 21 & 1.98 & 9 & 4.5 \\
\hline & 22 & 2.21 & 32 & 14.5 & 19 & 1.96 & 8 & 4.1 \\
\hline & Total & 9.17 & 110 & & & 8.2 & 43 & \\
\hline & Average $^{\mathrm{a}}$ Yield & & & 11.9 & & & & 5.2 \\
\hline \multicolumn{9}{|l|}{ Set B } \\
\hline & 12 & 2.1 & 45 & 21.4 & 6 & 2.2 & 19 & 8.6 \\
\hline & 35 & 1.38 & 26 & 18.8 & 18 & 1.9 & 20 & 10.5 \\
\hline & Average $^{\mathrm{a}}$ Yield & & & 20.1 & & & & 9.6 \\
\hline
\end{tabular}

${ }^{\mathrm{a}}$ The difference in average yield from each treatment for both Set $\mathrm{A}(p=.005)$ and Set $\mathrm{B}(p=.02)$ is significant

Milk production and quality

The total milking season production data for the year the dairy goats were fed in cycles of treated/untreated feed (2011/2012) was compared to the previous season (2010/2011). The data obtained from the Dairy Goat Cooperative showed that the combined milk solids production in the 2011/2012 season was $43864 \mathrm{~kg}$ : an increase of $33 \%$ compared to the previous season $(33027 \mathrm{~kg})$. The total milk volume production for the 2011/2012 season was 377848L: a 31\% increase compared to the previous season (2010/2011).

In dairy cows on the Hauraki Plains, the results directly from the cooperative milk processor's supply and quality analysis report showed cows grazing on

Table 4 Effect of pasture treatment on sale returns for Angus stud bulls grazed on Biozest ${ }^{\mathrm{TM}}$ treated pasture compared to untreated pasture

\begin{tabular}{|c|c|}
\hline \multicolumn{2}{|c|}{ Sales return on 20 bulls grazed on 20 ha $(\$)$} \\
\hline Control block & 92,300 \\
\hline Biozest $^{\mathrm{TM}}$ block & 128,200 \\
\hline Increase in returns & 35,900 \\
\hline Increase in returns $\mathrm{ha}^{-1}$ & 1,795 \\
\hline Cost of Biozest ${ }^{\mathrm{TM}} \mathrm{ha}^{-1}$ & 150 \\
\hline Net gain $\mathrm{ha}^{-1 \mathrm{a}}$ & 1,645 \\
\hline
\end{tabular}

${ }^{\mathrm{a}}$ Net gain ha-1 is significant $(p=.02)$
Biozest $^{\mathrm{TM}}$ treated pasture produced $8.5 \%$ more milk solids, $3.3 \%$ more milk protein and $12.2 \%$ more fat $\mathrm{L}^{-1}$ compared to when they were feeding on control (untreated) pasture.

\section{Urea discharge}

Urine tests from the Pukeatua dairy goat farm where goats were fed treated and control pasture in rotation showed less urea was discharged when dairy goats consumed Biozest $^{\mathrm{TM}}$ treated pasture and the urea discharge increased when they consumed control pasture (Fig. 2). The average difference in the ratio is $26 \%(p=0.03)$.

Data from the South Island dairy farm confirmed that when dairy cows were grazing on treated pasture, $36 \%$ less urea was discharged compared to when the same herd was grazing untreated control pasture $(p=0.138)$.

On the two dairy farms on the Hauraki Plains, urea testing results from the $1^{\text {st }}$ cycle of pasture grazing showed a reduction of $25 \%$ in one farm $(p=0.035)$ and $24 \%(p=0.012)$ in the other during the treated pasture grazing period compared to the control pasture grazing period. 
Fig. 2 Effect of pasture treatment cycles on urea excretion in dairy goats

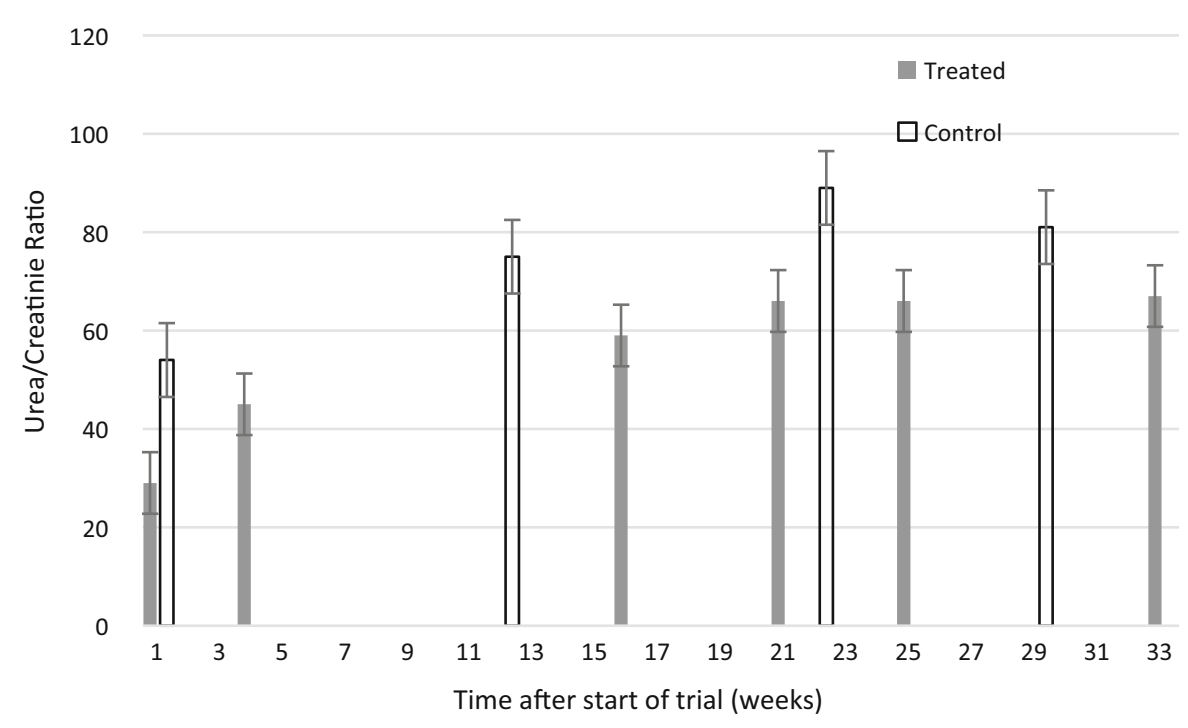

Table 5 Summary of the FARMAX model forecast of stock productivity ha ${ }^{-1}$ on Mangapapa (control) and Haumai (Biozest ${ }^{\mathrm{TM}}$ treated)

\begin{tabular}{lll}
\hline Stock Productivity $\mathrm{kg} \mathrm{ha}^{-1}$ & & \\
\hline & $\begin{array}{l}\text { Mangapapa } \\
\text { (control farm) }\end{array}$ & $\begin{array}{l}\text { Haumai } \\
\text { (Biozest treated) }\end{array}$ \\
\hline Current & 581 & 748 \\
FARMAX forecasted growth for the remainder of the season & 115 & 163 \\
Total (expected) for season & 696 & 911 \\
Expected productivity gain $\left(\mathrm{ha}^{-1}\right)$ & & 215 \\
Increased revenue at $\$ 4 \mathrm{~kg}^{-1}\left(\$ \mathrm{ha}^{-1}\right)$ & & 860 \\
Total Cost of Biozest & & 31 \\
Forecasted Net Gain $\left(\$ \mathrm{ha}^{-1}\right)$ & & 210 \\
\hline
\end{tabular}

Case study: sheep and cattle farm

The alpha marketing test data from 2 sheep and cattle farms located in Waikato, New Zealand, shows that in a whole farm scale, controlled, comparative trial, Biozest $^{\mathrm{TM}}$ applications on pasture can improve productivity by over $30 \%$ compared to the control farm (Table 5). The expected productivity gain is $215 \mathrm{~kg} \mathrm{ha}^{-1}$ with a net gain (financial gain, less cost of Biozest $^{\mathrm{TM}}$ and application costs) of NZ\$650 ha ${ }^{-1}$ (over \$130,000 for the 200 ha farm).

\section{Discussion}

The application of Biozest ${ }^{\mathrm{TM}}$ on crops and pasture delivers the range of phenomena attributable to phenylpropanoid cascades (Indigo Limited, unpublished reports). The full mechanism of the observed biological response has yet to be determined. However, field observations and data from several crops and pasture types support the hypothesis that membrane bound receptors on plant surfaces recognise and react to Biozest ${ }^{\mathrm{TM}}$ applications; inducing and sustaining the innate production of phenylpropanoid cascades and delivering the expected range of benefits, including improved growth and yield, improved pest and disease resilience and repair, reduced physiological 
issues, and improved quality and flavour (Indigo Limited, unpublished reports).

Increase in DM productivity and palatability

Plants sense physical and extrinsic molecular patterns and signals, such as pest, disease and environmental changes, and transmit this information throughout the plant to immediately activate repair growth and defence responses in undamaged parts (Toyota et al. 2018). Trial results suggest Biozest ${ }^{\mathrm{TM}}$ elicits a similar reaction when applied on pasture. The treated pasture is more resilient to environmental stresses, heathier and more productive. For example, 2 split paddocks on a Taranaki dairy farm treated with Biozest ${ }^{\mathrm{TM}}$ in winter (June) resulted in an increase of $89 \%$ and $127 \%$ in DM productivity 19 days after treatment (Table 1).

Farmers observed that livestock preferentially grazed treated pasture. This preference was confirmed when an almost equal amount of pasture was offered for grazing in a split block trial on a Northland dairy farm. The dairy cows grazed $21 \%$ more DM from the Biozest $^{\mathrm{TM}}$ treated area compared to the control (Table 2). Preferential grazing supports the hypothesis that the application of Biozest ${ }^{\mathrm{TM}}$ increases phenylpropanoids, including the flavour compound group: flavonoids (Panche et al. 2016). The higher content of flavonoids and the bouquet from aromatic flavonoids could have enabled the livestock to sort and preferentially graze Biozest ${ }^{\mathrm{TM}}$ treated pasture. In addition, Brix testing on an Auckland sheep farm confirmed that Biozest $^{\mathrm{TM}}$ treatment improves soluble sugars in pasture by $18 \%$. The improved content of soluble sugars could also have encouraged preferential grazing.

Increase in baleage yield

Full growth cycle results (Table 3) from 2 Hauraki Plains dairy farms show the baleage yield ha ${ }^{-1}$ from Biozest $^{\mathrm{TM}}$ treated farm paddocks increased by $117 \%$ compared to the control farm. In addition, treated paddocks that were grazed and then retreated with Biozest $^{\mathrm{TM}}$ produced $115 \%$ more bales than the untreated, control farm confirming the increase in production is sustainable (Table 3 ).

Field observations revealed larger leaf and wider spread of grass and clover crowns, confirming the mode of action of Biozest ${ }^{\mathrm{TM}}$ is different to fertilisers or hormones. $\mathrm{N}$ fertilisers generally suppress white clover (Harris et al. 1996). Applications of hormones such as gibberellic acid result in morphological changes and repeat applications produce negative responses (Bryant et al. 2016). Biozest ${ }^{\mathrm{TM}}$ treatment produces denser pasture cover. This increased ground cover maximises the utilisation of water, land and fertiliser resources and can therefore reduce leaching.

The substantial increase in pasture (baleage) production (117\% and $115 \%$ ) had no negative impact on feed quality and dry matter production (Zest Biotech, unpublished reports). Applying Biozest ${ }^{\mathrm{TM}}$, rather than the common practice of applying $\mathrm{N}$ fertilisers to meet feed budget demands, avoids the negative impact of excess $\mathrm{N}$ on livestock productivity. In addition, applying Biozest ${ }^{\mathrm{TM}}$ avoids the environmental impacts of $\mathrm{N}$ fertiliser application and the excretion of urine containing high concentrations of $\mathrm{N}$ (Pacheco and Waghorn 2008). The ability to produce more feed onfarm avoids the environmental cost of feed importation as well as the economic cost, which can be significant (FAO and GDP 2018).

Pasture productivity under stress conditions

Split block trials carried out on a farm in Northland, New Zealand, during the 2010 drought showed that, throughout the drought period, cows grazed more than double the amount of pasture $\mathrm{ha}^{-1}$ from the Biozest ${ }^{\mathrm{TM}}$ treated area compared to the control. In winter, the district had an unusual series of frosts. During this cold stress period, the cows grazed more than double the amount of pasture out of the Biozest ${ }^{\mathrm{TM}}$ treated area compared to the control.

In a mixed pasture paddock (ryegrass $60 \%$ and $40 \%$ drought tolerant Kikuyu (Pennisetum clandestinum)), the stock consumed more dry matter in the Biozest ${ }^{\mathrm{TM}}$ treated areas across all seasons. Even in the $\mathrm{C} 4$ Pennisetum pasture species, which are naturally drought tolerant, Biozest ${ }^{\mathrm{TM}}$ treatment improved productivity.

Controlled trials on a swampy/waterlogged paddock show that Biozest ${ }^{\mathrm{TM}}$ treatment enabled the pasture to overcome soil/water stress conditions during summer when shallow rooted pasture dries out and in winter/spring when the soil becomes waterlogged. The dairy cows consumed more than twice as much pasture from the Biozest ${ }^{\mathrm{TM}}$ treated area during the stress periods. 
Biozest $^{\mathrm{TM}}$ treatment in this series of trials resulted in climate resilient pasture, tolerant to drought, waterlogging and frost.

The ability of Biozest ${ }^{\mathrm{TM}}$ treated pasture to overcome abiotic stress and be more productive is supported by the results obtained from the use of another formulation from the same technology platform, trademarked Agrizest ${ }^{\mathrm{TM}}$. Agrizest $^{\mathrm{TM}}$ application enabled treated plants to overcome abiotic stress from salinity, herbicide contaminated soils, frost, and overcropping, and biotic stress from pest, disease and physiological damage. Reducing abiotic and biotic stress resulted in healthier and more productive trees and vines (Indigo Limited, unpublished reports). In addition, the flavour and colour of treated crops improved (Indigo Limited, unpublished reports). These benefits are attributable to phenylpropanoids (Sharma et al. 2019; Dixon and Paiva 1995).

The hypothesis that application of Biozest ${ }^{\mathrm{TM}}$ upregulates the biosynthesis of phenylpropanoids is supported by established science. The Slack, Roughan discovery of how plants desaturate fatty acid to linoleate (a precursor to omega oils) when subjected to chilling and other stresses, such as darkness or high hydrogen atmosphere (Slack et al. 1978), led to the inception of the Octadeconoid Pathway (Schaller 2001). When subjected to stress, plants swiftly upregulate the octadecanoid pathway. Membrane bound fatty acids are desaturated to linolenic acid. The signalling hormones jasmonic acid and ethylene accumulate and reach a threshold, upregulating the next level of defence reactions, resulting in the production of phenylpropanoid cascades. This knowledge of the biosynthesis of phenylpropanoids in response to stress and the role of phenylpropanoids in resistance to and recovery from abiotic and biotic stress supports the hypothesis that Biozest ${ }^{\mathrm{TM}}$ elicits phenylpropanoid biosynthesis, which results in healthier and more productive pasture.

Full life cycle productivity assessment and financial returns

The FARMAX ${ }^{\mathrm{TM}}$ farm modelling tool was used to predict farming and financial outcomes in a full life cycle, commercial scale sheep and cattle farm trial. The model predicted Biozest applications on pasture would improve productivity by over $30 \%$. If the meat schedule price was $\mathrm{NZ} \$ 4 \mathrm{~kg}^{-1}$, this increase in production would result in NZ\$650 increased net revenue $\mathrm{ha}^{-1}$.

The scale of the productivity improvement affirms the consensus among scientists that animal productivity can be increased by $30 \%$ by improving farm efficiencies (FAO 2019; Knapp et al. 2014).

Pasture productivity is increased when Biozest ${ }^{\mathrm{TM}}$ is applied due to the efficient utilisation of land and resources. For example, when Biozest is applied, no additional water or fertilisers are required to sustainably increase pasture productivity $\mathrm{Ha}^{-1}$. Additionally, when ruminants graze Biozest ${ }^{\mathrm{TM}}$ treated pasture, the feed conversion efficiency improves. The result is a substantial increase in farm net revenue.

Milk and meat productivity and links to environmental liabilities $\left(\mathrm{CH}_{4}, \mathrm{~N}_{2} \mathrm{O}\right.$ and urea)

Increasing milk solids and meat production may reduce feed waste in the form of $\mathrm{CH}_{4}$ and urea (Edouard et al. 2016; Castillo et al. 2000). This study demonstrated that grazing ruminants on Biozest ${ }^{\mathrm{TM}}$ treated pasture substantially increased milk and meat production. When 20 Angus breed stud bulls grazed on 20 ha of treated pasture, they gained an extra $22 \%$ in weight during the 68-day finishing period compared to the control bulls. Bulls that grazed Biozest ${ }^{\mathrm{TM}}$ treated pasture realised higher bids at auction due to improved body condition. The net return $\mathrm{ha}^{-1}$ increased by $\mathrm{NZ} \$ 1,645$. In the dairy goat full production trial, Biozest $^{\mathrm{TM}}$ treated pasture was cut and fed to dairy goats. The volume of feed was the same as the previous year, as was the herd size. However, the combined milk volume increased by $31 \%$, and the total milk solid production increased by $33 \%$ compared to the previous season. Biozest ${ }^{\mathrm{TM}}$, therefore, improved both the quantity and quality of milk.

The productivity improvements are due to the efficient conversion of pasture protein to milk and meat. The higher content of phenylpropanoids in Biozest $^{\mathrm{TM}}$ treated pasture forms conjugates with protein (Lee 2014) and therefore is indigestible in the rumen and, instead, undergoes intestinal digestion to amino acids which the livestock convert directly to milk and meat protein. The higher content of phenylpropanoids in pasture can shift the type of $\mathrm{N}$ excreted in urine and dung from a soluble form to an insoluble form of $\mathrm{N}$ (Patra 2011). This beneficial effect on $\mathrm{N}$ cycling and reduction of leaching has not been 
examined in this study. However, a key finding from the dairy goat full production trial was that urine urea excretion was reduced in the range of $20 \%$ to $40 \%$. Short term trials on dairy cow farms confirmed that when cows graze Biozest ${ }^{\mathrm{TM}}$ treated pasture, milk solid production increases and urea excretion is reduced. Similar results were reported by Castillo et al. (2000), reflecting the known relationship between ruminant productivity and urea excretion.

Of further interest is the relationship between urea excretion and methane emissions. In all animals (including ruminants), the intestinal digestive system catabolises protein to amino acids. In the ruminant digestive system, the protein is digested further. Amino acids from digested protein are deaminated to $\mathrm{NH}_{3}$, carbonyl and hydride. Bacteria in the rumen can only use $\mathrm{NH}_{3}$ to synthesise protein. However, the rumen bacteria are unable to utilise $\mathrm{NH}_{3}$ at the rate it is produced. Therefore, the liver removes the excess and converts it to urea and, via the kidneys, discharges it in the urine. The residual carbonyls and hydride moieties undergo methylotrophic and hydrogenotrophic methanogenesis and are released as $\mathrm{CH}_{4}$. Therefore, there is a direct relationship between urea production and $\mathrm{CH}_{4}$ emission in ruminant digestion (CarmonaFlores et al. 2020).

The relationship between urea production and $\mathrm{CH}_{4}$ emissions may be positively exploited by using phenylpropanoids. The benefits of phenylpropanoids on ruminant efficiency and GHG production are well established. When fed as a supplement, specific phenylpropanoids or a mix of phenylpropanoids directly inhibit methanogens and likely act as hydride sinks via the cleavage of ring structures (Patra 2011) and reductive dihydroxylation. However, researchers have so far been unsuccessful in producing sustained effects without side effects. Elaborate on this. Biozest $^{\mathrm{TM}}$ can overcome these constraints because the phenylpropanoids are not used as antibiotics. The mode of action of Biozest instead relies on the pasture de novo synthesised phenylpropanoids complexing with pasture proteins and protecting protein from digestion in the rumen (Lee 2014). When ruminant livestock consume Biozest ${ }^{\mathrm{TM}}$ treated pasture, the higher content of phenylpropanoids can complex with more of the pasture protein. The resulting conjugates are protected from digestion and deamination in the rumen. Instead, they are digested more efficiently in the intestine to amino acids and utilised in milk and meat protein production. As a result of the reduced digestion of protein in the rumen, less deamination occurs, and, therefore, less protein is wasted as urea and $\mathrm{CH}_{4}$. Because of the reduction in urea excretion as measured in trials, we deduce that deamination has likely been reduced. Therefore, $\mathrm{CH}_{4}$ production would also have been reduced in livestock consuming Biozest $^{\mathrm{TM}}$ treated pasture.

A second strategy that may be employed to reduce $\mathrm{CH}_{4}$ emissions is to increase the relative amount of soluble carbohydrates in pasture. Higher soluble sugar content in pasture favours the production of more propionic acid relative to acetic acid, resulting in less $\mathrm{CH}_{4}$ production. We have not measured the $\mathrm{CH}_{4}$ reduction, but the data shows soluble sugars are higher in Biozest ${ }^{\mathrm{TM}}$ treated pasture than in untreated pasture. Therefore, we deduce that Biozest ${ }^{\mathrm{TM}}$ treatment of pasture has an added benefit in reducing $\mathrm{CH}_{4}$ production during carbohydrate digestion in the ruminant.

To summarise, the results support several inferences. First, when dairy cows and goats consume Biozest $^{\mathrm{TM}}$ treated pasture, urea excretion is reduced between 20 and $48 \%$. Therefore $\mathrm{N}_{2} \mathrm{O}$ production from excreta will be reduced. The reduction in urea excretion is a result of a reduction in deamination. The generation of carbonyls and hydride during the deamination process is also reduced, resulting in less methylotrophic and hydrogenotrophic methanogenesis. Secondly, during carbohydrate digestion, the higher content of soluble sugars (18\% on an Auckland sheep farm) in treated pasture favours the production of propionate rather than acetate and butyrate. Therefore, acetoclastic methanogenesis is reduced.

New Zealand pasture contains more $\mathrm{N}$ than ruminants can utilise. However, farmers often apply $\mathrm{N}$ fertilisers to achieve the required feed budgets. While $\mathrm{N}$ fertilisers increase pasture growth, excess $\mathrm{N}$ negatively impacts animal and environmental welfare (Pacheco and Waghorn 2008). Unlike N, the previously described results from a range of farm types demonstrate that Biozest ${ }^{\mathrm{TM}}$ can sustainably double pasture productivity and when ruminants consume Biozest $^{\mathrm{TM}}$ treated pasture, milk and meat production increases, and less urea is excreted. Based on the direct link between soluble sugar content and $\mathrm{CH}_{4}$ production and urea excretion and $\mathrm{CH}_{4}$ production, and potential avoidance of the direct application of urea to pasture for pasture growth, we deduce that Biozest will substantially reduce environmental liabilities. 


\section{Conclusion}

Biozest can enable pastoral farmers to reduce environmental impact and increase food security. When ruminants graze Biozest treated pasture, milk and meat productivity increases and less pasture is wasted in the form of urea excreted in urine. The urea reduction suggests less deamination of pasture protein and methanogenesis can occur. Because less urea is excreted, it follows, less $\mathrm{N}_{2} \mathrm{O}$ is produced. The results presented are further evidence of the link between increased productivity and reduction in urea excretion. However, in this study, the plausible reduction in $\mathrm{N}_{2} \mathrm{O}$ and $\mathrm{CH}_{4}$ emissions that likely follows a reduction in deamination and urea excretion has not been quantified.

Carbon sequestration is a crucial area that requires further investigation via direct measurement or modelling. By doubling pasture productivity, every ha of Biozest $^{\mathrm{TM}}$ treated pasture could double DM production and therefore possibly double the sequestration of atmospheric $\mathrm{CO}_{2}$ compared to untreated paddocks or sequester 3 times the $\mathrm{C}$ that forestry is capable of. Quantification of the increased C sequestered would enable farmers to earn carbon credits.

Stock graze Biozest ${ }^{\mathrm{TM}}$ treated paddocks more evenly. Therefore, the liability of post-grazing residual pasture decomposition and resulting emissions of $\mathrm{CH}_{4}$ and $\mathrm{CO} 2$ are reduced. In addition, the denser pasture growth covers more land, maximising resource utilisation which could further reduce environmental impact by reducing the leaching of nutrients.

Further work should be carried out on the type and quantity of urea excreted to land and consequent impacts on nitrate leaching using both the collection of urea from grazing animals in field-based trials and a model, such as GLEAM, to quantify GHGs and environmental footprint. Results may then guide livestock management and stocking rates and will result in meticulous climate change management and food security policy decisions. Observations from trial work and made by farmers, such as soil firmness even in wet conditions, thicker animal dung, easier calving/ lambing, less incidence of mastitis, indicate that there may be wider benefits in terms of soil and animal health that are yet to be explored. Work into the influence of phenylpropanoids on the proliferation of microflora that convert fertiliser and soil minerals to plant available forms may reveal additional opportunities to reduce leaching and water pollution.

Acknowledgements The authors would like to thank those farmers and dairy companies who allowed us to conduct this research and assisted with the collection and provision of data.

Author contributions Both authors contributed to the design of the study and data interpretation and drafted and edited the manuscript.

\section{Declarations}

Conflicts of interest Both Nathan Balasingham and Usha Amaranathan are employees and directors of Zest Biotech, owner of the Biozest ${ }^{\mathrm{TM}}$ technology. All trial work has been carried out independently with data and samples collected and supplied by farmers or reported by dairy companies.

Open Access This article is licensed under a Creative Commons Attribution 4.0 International License, which permits use, sharing, adaptation, distribution and reproduction in any medium or format, as long as you give appropriate credit to the original author(s) and the source, provide a link to the Creative Commons licence, and indicate if changes were made. The images or other third party material in this article are included in the article's Creative Commons licence, unless indicated otherwise in a credit line to the material. If material is not included in the article's Creative Commons licence and your intended use is not permitted by statutory regulation or exceeds the permitted use, you will need to obtain permission directly from the copyright holder. To view a copy of this licence, visit http://creativecommons.org/licenses/by/4.0/.

\section{References}

Balsom T, Lynch G (2008) Monitoring pasture quality using Brix measurements - Novel Ways. https://www.novel.co. nz/brix/. Accessed 6 Jun 2017

Bryant R, Edwards G, Robinson B (2016) Comparing response of ryegrass-white clover pasture to gibberellic acid and nitrogen fertiliser applied in late winter and spring. $\mathrm{N} Z \mathrm{~J}$ Agric Res 59:18-31. https://doi.org/10.1080/00288233. 2015.1119164

Calsamiglia S, Busquet M, Cardozo PW, Castillejos L, Ferret A (2007) Invited review: essential oils as modifiers of rumen microbial fermentation. J Dairy Sci 90:2580-2595. https:// doi.org/10.3168/jds.2006-644

Carmona-Flores L, Bionaz M, Downing T, Sahin M, Cheng L, Ates S (2020) Milk production, N partitioning, and methane emissions in dairy cows grazing mixed or spatially separated simple and diverse pastures. Animals 10:1301. https://doi.org/10.3390/ani10081301

Castillo A, Kebreab E, Beever D, France J (2000) A review of efficiency of nitrogen utilisation in lactating dairy cows and its relationship with environmental pollution. J Animal Feed Sci 9(1):1-32. https://doi.org/10.22358/jafs/68025/ 2000 
Chinnusamy V, Schumaker K, Zhu J-K (2003) Molecular genetic perspectives on cross-talk and specificity in abiotic stress signalling in plants. J Exp Bot 55:225-236. https:// doi.org/10.1093/jxb/erh005

Dixon R, Paiva N (1995) Stress-induced phenylpropanoid metabolism. Plant Cell 7:1085-1097

Eckard RJ, Grainger C, de Klein CAM (2010) Options for the abatement of methane and nitrous oxide from ruminant production: A review. Livest Sci 130:47-56. https://doi. org/10.1016/j.livsci.2010.02.010

Edouard N, Hassouna M, Robin P, Faverdin P (2016) Low degradable protein supply to increase nitrogen efficiency in lactating dairy cows and reduce environmental impacts at barn level. Anim Int J Anim Biosci 10:212-220. https://doi. org/10.1017/S1751731115002050

Fang FC, Casadevall A (2011) Reductionistic and holistic science. Infect Immun 79:1401-1404. https://doi.org/10. 1128/IAI.01343-10

FAO and GDP (2018) Climate change and the global dairy cattle sector - The role of the dairy sector in a low-carbon future. Rome. 36 pp. Licence: CC BY-NC-SA- 3.0 IGO

FAO (2017) Livestock solutions for climate change. http:// www.fao.org/3/i8098e/i8098e.pdf. Accessed 24/08/2021

FAO (2019) FAO's work on climate change. http://www.fao. org/3/ca7126en/ca7126en.pdf. Accessed 24/08/2021

Farmax Ltd FARMAX - About farmax. http://www.farmax.co. nz/about. Accessed 30 Jul 2020

Harris SL, Clark DA, Waugh CD, Clarkson FH (1996) Nitrogen fertiliser effects on white clover in dairy pastures. NZGA R\&P Series 6:119-124. https://doi.org/10.33584/rps.6. 1995.3350

Harrison MJ, Baldwin IT (2004) Biotic interactions ploy and counter-ploy in the biotic interactions of plants - Editorial overview. Curr Opin Plant Biol 7:353-355. https://doi.org/ 10.1016/j.pbi.2004.05.012

Hassan S, Mathesius U (2012) The role of flavonoids in rootrhizosphere signalling: opportunities and challenges for improving plant-microbe interactions. $J$ Exp Bot 63:3429-3444. https://doi.org/10.1093/jxb/err430

Hristov AN, Jouany JP Factors affecting the efficiency of nitrogen utilization in the rumen. In: Nitrogen and phosphorus nutrition of cattle: reducing the environmental impact of cattle operations. CABI, Wallingford, pp 17-166

IPCC (Intergovernmental Panel on Climate Change) (2019) IPCC updates methodology for greenhouse Gas inventories - IPCC. https://www.ipcc.ch/2019/05/13/ipcc-2019refinement/. Accessed 8 Jul 2021

IPCC (Intergovernmental Panel on Climate Change) (ed) (2014) Climate Change 2014: Synthesis Report. Contribution of Working Groups I, II and III to the Fifth Assessment Report of the Intergovernmental Panel on Climate Change [Core Writing Team, R.K. Pachauri and L.A. Meyer (eds.)]. IPCC, Geneva, Switzerland, $151 \mathrm{pp}$

Johnson KA, Johnson DE (1995) Methane emissions from cattle. J Anim Sci 73:2483-2492

Knapp JR, Laur GL, Vadas PA, Weiss WP, Tricarico JM (2014) Invited review: enteric methane in dairy cattle production: quantifying the opportunities and impact of reducing emissions. J Dairy Sci 97:3231-3261. https://doi.org/10. 3168/jds.2013-7234
Lee MRF (2014) Forage polyphenol oxidase and ruminant livestock nutrition. Front Plant Sci 5:694-694. https://doi. org/10.3389/fpls.2014.00694

Leng RA 188381 (1991) Improving ruminant production and reducing methane emissions from ruminants by strategic supplementation

Litherland AJ, Webby R, Fraser TJ et al (2008) Indirect measurement of pasture mass and pasture growth rate on sheep and beef pastures. Proc N Z Grassl Assoc 70:137-144

Merfield CN, Johnson M (2016) Understanding biostimulants, biofertilisers and on-farm trials. Lincoln, New Zealand

Moe PW, Tyrrell HF (1979) Methane production in dairy cows. J Dairy Sci 62:1583-1586. https://doi.org/10.3168/jds. S0022-0302(79)83465-7

Neal JS, Fulkerson WJ, Lawrie R, Barchia IM (2009) Difference in yield and persistence among perennial forages used by the dairy industry under optimum and deficit irrigation. Crop Pasture Sci 60:1071. https://doi.org/10.1071/ CP09059

NIWA (2011) NIWA Media Release: 12 January 2011 New Zealand national climate summary 2010: Settled and warm

Nürnberger T, Brunner F, Kemmerling B, Piater L (2004) Innate immunity in plants and animals: striking similarities and obvious differences. Immunol Rev 198:249-266. https:// doi.org/10.1111/j.0105-2896.2004.0119.x

Pacheco D, Waghorn GC (2008) Dietary nitrogen - definitions, digestion, excretion and consequences of excess for grazing ruminants. Proc New Zealand Grassland Assoc. https:// doi.org/10.33584/jnzg.2008.70.2738

Panche AN, Diwan AD, Chandra SR (2016) Flavonoids: an overview. J Nutr Sci. https://doi.org/10.1017/jns.2016.41

Panstruga R, Parker JE, Schulze-Lefert P (2009) SnapShot: Plant immune response pathways. Cell 136:978.e1-978.e3. https://doi.org/10.1016/j.cell.2009.02.020

Patra A (2011) Effects of essential oils on rumen fermentation, microbial ecology and ruminant production. Asian J Anim Vet Adv 6:416-428. https://doi.org/10.3923/ajava.2011. 416.428

Schaller F (2001) Enzymes of the biosynthesis of octadecanoidderived signalling molecules. J Exp Bot 52:11-23. https:// doi.org/10.1093/jexbot/52.354.11

Sharma A, Shahzad B, Rehman A, Bhardwaj R, Landi M, Zheng B (2019) Response of phenylpropanoid pathway and the role of polyphenols in plants under abiotic stress. Molecules. https://doi.org/10.3390/molecules24132452

Slack CR, Roughan PG, Balasingham N (1978) Labelling of glycerolipids in the cotyledons of developing oilseeds by [1-14C]acetate and [2-3H]glycerol. Biochem J 170:421-433

Tait A (2011) Droughts. In: NIWA. https://niwa.co.nz/naturalhazards/hazards/droughts. Accessed 17 Jun 2020

Theodorou MK, Kingston-Smith AH, Winters AL, Lee MRF, Minchin FR, Morris P, MacRae J (2006) Polyphenols and their influence on gut function and health in ruminants: a review. Environ Chem Lett 4:121-126. https://doi.org/10. 1007/s10311-006-0061-2

Toyota M, Spencer D, Sawai-Toyota S, Jiaqi W, Zhang T, Koo A, Howe G, Gilroy S (2018) Glutamate triggers long-distance, calcium-based plant defense signaling. Science 361:1112-1115. https://doi.org/10.1126/science.aat7744 
Wang K, Nan X, Chu K, Tong j, Yang L, Zheng S, Zhao G, Jiang L, Xiong B, (2018) Shifts of hydrogen metabolism From methanogenesis to propionate production in response to replacement of forage fiber with non-forage fiber sources in diets in vitro. Front Microbiol. https://doi.org/10.3389/ fmicb.2018.02764
Publisher's Note Springer Nature remains neutral with regard to jurisdictional claims in published maps and institutional affiliations. 